\title{
Study of the Phytochemical Composition, the Antioxidant and the Anti-Inflammatory Effects of Two Sub-Saharan Plants: Piliostigma reticulatum and Piliostigma thonningii
}

\author{
K. Boualam $\left(\mathbb{D},{ }^{1,2}\right.$ B. Ndiaye $\left(\mathbb{D},{ }^{3}\right.$ H. Harhar $\left(\mathbb{D},{ }^{1}\right.$ M. Tabyaoui $\left(\mathbb{D},{ }^{1}\right.$ N. Ayessou $\left(\mathbb{D},{ }^{3}\right.$ \\ and K. Taghzouti iD ${ }^{2}$ \\ ${ }^{1}$ Laboratory of Materials, Nanotechnology and Environment, Faculty of Sciences-Rabat, Mohammed V \\ University of Rabat, BP 1014-Rabat, Morocco \\ ${ }^{2}$ Genomics of Human Pathologies Research Center, Faculty of Sciences, Mohammed V University in Rabat, BP1014 \\ Rabat, Morocco \\ ${ }^{3}$ Electrochemistry and Membrane Processes Laboratory LEPM, Polytechnics School, Cheikh Anta Diop University, \\ PB 5085 Dakar, Senegal
}

Correspondence should be addressed to H. Harhar; hichamoo79@yahoo.fr

Received 20 January 2021; Accepted 25 April 2021; Published 4 May 2021

Academic Editor: Abdeslam Jaafari

Copyright (c) $2021 \mathrm{~K}$. Boualam et al. This is an open access article distributed under the Creative Commons Attribution License, which permits unrestricted use, distribution, and reproduction in any medium, provided the original work is properly cited.

\begin{abstract}
The aim of this study is to perform phytochemical screening of the leaves of Piliostigma reticulatum and Piliostigma thonningii, to determine the phenolic, flavonoids, tannins, and sugars content in their methanolic extracts, evaluate their antioxidant activity using the DPPH and the ABTS tests, and test their anti-inflammatory effect in vitro using the heat-induced albumin denaturation inhibition method. Phytochemical screening revealed the presence of polyphenols and alkaloids in the leaves of both plants. Yields of the extracts in this study ranged from $7 \%$ to $18 \%$ for P. reticulatum and $4 \%$ to $16 \%$ for $P$. thonningii. The phenolic content in the methanolic extract of $P$. reticulatum is $74.66 \pm 1.76 \mu \mathrm{g} \mathrm{GAE} / \mathrm{mL}$, which is significantly higher than that of $P$. thonningii $(56.54 \pm 1.24 \mu \mathrm{g} \mathrm{GAE} / \mathrm{mL})$. Both plants showed good antioxidant activity. In fact, for the DPPH test, the IC50 value is $8.88 \pm 0.11 \mu \mathrm{g} / \mathrm{mL}$ for $P$. reticulatum and $17.64 \pm 0.68 \mu \mathrm{g} / \mathrm{mL}$ for $P$. thonningii. For the ABTS assay, the $\mathrm{IC}_{50}$ values of the two plants are, respectively, $9.78 \pm 1.83 \mu \mathrm{g} / \mathrm{mL}$ and $13.47 \pm 2.62 \mu \mathrm{g} / \mathrm{ml}$, statistically comparable and significantly higher than the $\mathrm{IC}_{50}$ of the standard $30.76 \pm 0.18 \mu \mathrm{g} / \mathrm{ml}$. Leaf extracts from both plants were effective against heat-induced denaturation of albumin. The activity of $P$. reticulatum is indeed comparable to that of the standard with an $\mathrm{IC}_{50}$ value of $121.43 \pm 1.55 \mu \mathrm{g} / \mathrm{mL}$ and higher than that of $P$. thonningii with an $\mathrm{IC}_{50}$ value of $170.15 \pm 1.09 \mu \mathrm{g} / \mathrm{mL}$. These results show that both plants exhibit significant antioxidant and anti-inflammatory activities. Therefore, their chemical compounds could have potential applications as antioxidant and anti-inflammatory drugs.
\end{abstract}

\section{Introduction}

Oxidative stress occurs when cells undergo an excessive production of oxygenated free radicals that exceeds their antioxidant power [1]. Oxidative stress can lead to inflammation in many situations such as excess temperature and radiation but it is often its consequence [2]. Oxygenated free radicals are mediators of inflammation that intervene during phagocytosis or to maintain the inflammatory state [3-5]. Indeed, the superoxide ion $\left(\mathrm{O}_{2}^{-}\right)$is implicated in the proliferation of fibroblasts, oxygen peroxide $\left(\mathrm{H}_{2} \mathrm{O}_{2}\right)$ acts in the activation of transcription factors such as $\mathrm{NFkB}$, and nitric oxide (NO) intervenes in the regulation of vascular tone [6]. The close relationship between oxidative stress and inflammation may explain why molecules with an antioxidant effect make good candidates for anti-inflammatory treatments [7]. The interest of this study in anti-inflammatory activity is due to the fact that inflammation is an essential component of all chronic diseases as there is increasing evidence suggesting that excessive inflammation has a great impact on the physiopathology of stress-related diseases, which today constitutes $75 \%$ to $90 \%$ of human 
pathologies [8]. Since ancient times, plants have played a significant role in the treatment of many diseases. In this study, we aimed to compare the antioxidant and antiinflammatory activities of two very similar and widely used Sub-Saharan tries: Piliostigma reticulatum and Piliostigma thonningii. These plants belong to the Caesalpinia family and are present throughout the area between Senegal and Sudan [9]. Morphologically, these two shrubs attain 5-10 m height [10], look alike, and can easily be confused especially in Senegal; they have the same vernacular name "Nguiguis" [11]. However, P. thonningii can be distinguished by a ferruginous pubescence below the pods and leaves, which are less split and larger than those of $P$. reticulatum [8-12]. In traditional medicine, all parts of these shrubs are used. The leaves contain very similar essential oils with an antibacterial effect [8], and their use in infusion or decoction is very effective against several diseases with an inflammatory background such as abdominal pain, rheumatism, headaches, and injuries [10]. In the present study, for the phenols and sugars content of the leaves of these two plants, the antioxidant and anti-inflammatory effects of their methanol extracts were assessed in order to elucidate their therapeutic properties.

\section{Materials and Methods}

2.1. Preparation of Extracts. The leaves of Piliostigma reticulatum and Piliostigma thonningii were collected at the Botanical garden of Cheikh Anta Diop University in Dakar. They were dried under shade for two weeks, powdered, then weighed for extraction. We used different solvents with increasing polarity: petroleum ether $(\mathrm{PE})$, dichloromethane (DCM), dichloromethane/methanol (80/20), and methanol. $20 \mathrm{~g}$ of each plant was macerated with $200 \mathrm{~mL}$ of each solvent for four days at room temperature with continuous agitation. The obtained extracts were filtered then concentrated to dryness under pressure in a rotary evaporator. The crude extracts were stored at $4^{\circ} \mathrm{C}$ for further use.

2.2. Preliminary Phytochemical Screening. Qualitative tests protocols previously described by Kwaji et al. $[13,14]$ were used to detect the presence or the absence of alkaloids (Dragendorff, Mayer, and Wagner reagent), flavonoids (MgHCL test), tannins (ferric chloride reagent), terpenoides (chloroform and concentrated $\mathrm{HSO}_{4}$ ), sterols (reaction of Liebermann), and saponosides.

2.3. Determination of Total Phenolic Content (TPC). The methanol leaf extracts of the two plants were used to determine the concentration of the phenolic content following the protocol of Folin Ciocalteu assay [15] with slight modifications. A solution of the crude extract diluted in methanol was prepared at a concentration of $1000 \mu \mathrm{g} / \mathrm{mL}$, from which two other dilutions were prepared: $500 \mu \mathrm{g} / \mathrm{mL}$ and $250 \mu \mathrm{g} / \mathrm{mL}$. $0.5 \mathrm{~mL}$ of each concentration was mixed with $2.5 \mathrm{~mL}$ of Folin-Ciocalteu reagent $(10 \%)$ and $4 \mathrm{~mL}$ of $\mathrm{Na}_{2} \mathrm{CO}_{3}(7.5 \%)$. After $30 \mathrm{~min}$ of incubation at $45^{\circ} \mathrm{C}$, the absorbance was measured at $765 \mathrm{~nm}$. Values were compared to a blank sample. Results were expressed as gallic acid equivalent (GAE) in $\mu \mathrm{g} / \mathrm{mL}$. The standard curve was drawn by plotting the absorbance against the concentration of gallic acid. The samples were analyzed in triplicate.

2.4. Determination of Total Flavonoid Content (TFC). The content of flavonoids was determined by a colorimetric method using aluminum chloride [15]. $0.5 \mathrm{~mL}$ of diluted methanolic extract of each plant $(1 \mathrm{mg} / \mathrm{mL})$ was mixed with $3.2 \mathrm{~mL}$ of distilled water and $150 \mu \mathrm{L}$ of $\mathrm{NaNO}_{2}$ (5\%). After $5 \mathrm{~min}, 150 \mu \mathrm{L}$ of $\mathrm{AlCl}_{3}(10 \%)$ was added, and then after $6 \mathrm{~min}, 1 \mathrm{~mL}$ of $\mathrm{NaOH}(1 \mathrm{M})$ was added. After $30 \mathrm{~min}$ of incubation at room temperature, the absorbance of the solution was read at $510 \mathrm{~nm}$. Quantification of TFC was based on the standard curve of Quercetin solution. Flavonoids content was expressed as the Quercetin equivalent in $\mu \mathrm{g}$ per $1 \mathrm{~mL}$ of extract. The samples were analyzed in triplicate.

2.5. Determination of Total Tannins Content (TTC). The modified Broadhurst and Jones method [15] was followed to determine the Tannins Content in both plants' methanol leaves extracts, using catechin as a reference compound. $100 \mu \mathrm{L}$ of extract $(1 \mathrm{mg} / \mathrm{mL})$ was added to $3 \mathrm{~mL}$ of a solution of vanillin ( $4 \%$ in methanol) and $1.5 \mathrm{~mL}$ of concentrated $\mathrm{HCl}$. After $2 \mathrm{~min}$ of incubation in obscurity, the absorbance was read at $500 \mathrm{~nm}$. The TTC was calculated by a calibration curve of catechin. Tannins content was expressed as the catechin equivalent in $\mu$ g per $1 \mathrm{~mL}$ of extract. The sample was analyzed in triplicate.

2.6. Determination of Total Sugars Content (TSC). The sulfuric acid-phenol method [16] was used to determine the total sugar content in $P$. reticulatum and $P$. thonningii methanol leaves extracts. $1 \mathrm{~mL}$ of the extract $(1 \mathrm{~mL} / \mathrm{mg})$ was added to $1 \mathrm{~mL}$ of phenol (5\%), and then we added $5 \mathrm{~mL}$ of concentrated sulfuric acid $\left(\mathrm{H}_{2} \mathrm{SO}_{4}\right)$. After 10 min of agitation and $30 \mathrm{~min}$ of incubation at $30^{\circ} \mathrm{C}$, the absorbance was read at $488 \mathrm{~nm}$. The TSC was determined using a calibration curve of glucose. The sugars content was expressed as the $G$ equivalent in $\mu \mathrm{g}$ per $1 \mathrm{~mL}$ of extract. The sample was analyzed in triplicate.

\subsection{Antioxidant Activity}

2.7.1. DPPH Test. The antiradical activity of both extracts was tested using the 2.2-diphenyl-1-picryl-hydrazyl (DPPH) with ascorbic acid as a positive control [17]. $0.5 \mathrm{~mL}$ of DPPH $(79 \mu \mathrm{g} / \mathrm{mL})$ was added to a concentration range of extract $(5-100 \mu \mathrm{g} / \mathrm{mL})$. The reaction was then incubated for $30 \mathrm{~min}$ in obscurity at room temperature. When DPPH is reduced by an antioxidant molecule, its violet color turns yellow. The absorbance was read at $517 \mathrm{~nm}$ and the scavenging activity was estimated in percentage using the following equation: 
Free radical scavenging $(\%)=\frac{(O . D \text { control }-O . D \text { test })}{O . D \text { control })} * 100$

$\mathrm{IC}_{50}$ was estimated using the graph of free radical scavenging against extract and standard concentrations. The concentrations were tested three times and the average was calculated.

2.7.2. ABTS Essay. The test is based on the ability of an antioxidant to stabilize the blue-green colored cationic radical $\mathrm{ABTS}^{+}$(2,2- azinobis-3-ethylbenzothiazoline-6sulfate) by trapping a proton and transforming it into colorless $\mathrm{ABTS}^{+}[18]$.

A solution of ABTS (7 Mm) was prepared by mixing $72 \mathrm{mg}$ of ABTS with $13.24 \mathrm{mg}$ of potassium persulfate $(2.45 \mathrm{mM})$ in $20 \mathrm{~mL}$ of distilled water. The mixture was incubated for 16 hours in the dark. The ABTS-+ solution $(7 \mathrm{mM})$ was diluted with distilled water to reach an absorbance of $0.7 \pm 0.02$ at $734 \mathrm{~nm} .1 .9 \mathrm{~mL}$ of this solution has been added to $600 \mu \mathrm{L}$ of extract solution at different concentrations $(5-100 \mu \mathrm{g} / \mathrm{mL})$ [19]. After incubation for $7 \mathrm{~min}$ at room temperature, the absorbance was measured at $734 \mathrm{~nm}$.

The blank was prepared by replacing the extract solution with methanol. The scavenging activity was estimated in percentage using the following equation:

Free radical scavenging $(\%)=\frac{(O . D \text { control }-O . D \text { test })}{\text { O.D control })} * 100$.

$\mathrm{IC}_{50}$ was estimated using the graph of free radical scavenging against extract and standard concentrations. The concentrations were tested three times and the average was calculated.

2.8. Anti-Inflammatory Activity. To assess the anti-inflammatory activity of $P$. reticulatum and $P$. thonningii leaves, the inhibition of heat-induced protein denaturation protocol $[20,21]$ was followed with minor modifications. Diclofenac sodium was used as the reference drug. $0.05 \mathrm{~mL}$ of various concentrations $(40 \mu \mathrm{g} / \mathrm{mL}$ to $1000 \mu \mathrm{g} / \mathrm{mL})$ of extracts and the reference was mixed with $0.45 \mathrm{~mL}$ of bovine albumin (BSA) (5\%) and the $\mathrm{pH}$ was fixed at 6.3 with $1 \mathrm{~N} \mathrm{HCl}$.

The mixture tubes were incubated at $37^{\circ} \mathrm{C}$ for $20 \mathrm{~min}$; then, the temperature was raised to $57^{\circ} \mathrm{C}$ for $20 \mathrm{~min} .2 .5 \mathrm{~mL}$ of phosphate buffer solution (PBS) $(\mathrm{pH}=6.3)$ was added to each reaction tube and the absorbance was measured at $660 \mathrm{~nm}$. The control test tube contained distilled water and BSA; the product control test tube contained distilled water and the extract. The percentage of inhibition was calculated using the following formula:

The percentage of inhibition $(\%)=\frac{(O \cdot D \text { control }-O \cdot D \text { test })}{O \cdot D \text { control })} * 100$.
All the concentrations were tested three times, and the average was used.

2.9. Statistical Study. The total phenolic-sugar contents, antioxidant, and in vitro anti-inflammatory activities assay results were shown as means $\pm \mathrm{SD}$ of triplicate readings $(n=3)$. Data were analyzed with GraphPad Prism 6 version 6.01 and evaluated using an unpaired $t$-test and one-way analysis of variance ANOVA followed by Tukey's multiple comparisons test. The differences were regarded as statistically significant at $p<0.05$.

\section{Results and Discussion}

3.1. Yields and Phytochemical Screening. Four extracts with different colors and aspects were obtained for each plant. Extraction yields are reported in Figure 1. The yields ranges are from $7 \%$ to $18 \%$ for $P$. reticulatum and $4 \%$ to $16 \%$ for $P$. thonningii. For each solvent, there is no significant difference between the yields of the two plants extracts. The higher the polarity of the solvents is, the higher the yields of the extracts are. Therefore, the yield of the methanolic extract is more important for both plants.

Preliminary phytochemical screening results are grouped in Table 1 . Both $P$. reticulatum and $P$. thonningii leaves contain polyphenols, tannins, flavonoids, and alkaloids. Steroids were only found in Petroleum Ether and dichloromethane $P$. thonningii leaves extract, while DCM/ methanol and DCM extracts showed the presence of terpenoids in $P$. reticulatum. Only $P$. thonningii leaves contain saponins. Extracts with the solvents DCM/MeOH and $\mathrm{MeOH}$ have a higher concentration of phytochemicals compared to other solvents.

3.2. Total Phenol, Flavonoids, Tannins, and Sugars Content. Given the fact that phytochemical compounds are more concentrated in methanol extracts, we chose to use them to continue our study. Total phenol content (TPC) estimated from the calibration curve of gallic acid showed that the methanol extracts of the two plants $P$. reticulatum and $P$. thonningii contain $74.66 \pm 1.76 \mathrm{GAE} \mu \mathrm{g} / \mathrm{mL}$ and $56.54 \pm 1.24 \mathrm{GAE} \mu \mathrm{g} / \mathrm{mL}$, respectively. Total flavonoids (TFC), calculated using quercetin as a standard, showed that the concentration of flavonoids in $P$. thonningii methanol leaf extract is high $(21.59 \pm 0.75 \mathrm{QE} \mu \mathrm{g} / \mathrm{mL})$ comparing to P. reticulatum methanol leaf extract $(13.57 \pm 0.92 \mathrm{QE} \mu \mathrm{g} / \mathrm{mL})$. According to the calibration curve of catechin, $P$. reticulatum methanol leaf extract contains more tannin $(58.29 \pm 0.94 \mathrm{CE}$ $\mu \mathrm{g} / \mathrm{mL})$ than the $P$. thonningii extract $(33.87 \pm 1.09 \mathrm{CE} \mu \mathrm{g} / \mathrm{mL})$. The concentration of total sugars in $P$. reticulatum methanol leaf extract is high $(71.79 \pm 2.57 \mathrm{GE} \mu \mathrm{g} / \mathrm{mL})$ comparing to P. thonningii methanol leaf $(13.34 \pm 1.82 \mathrm{GE} \mu \mathrm{g} / \mathrm{mL})$ (Table 2).

\subsection{Antioxidant Activity}

3.3.1. DPPH Test. The DPPH scavenging ability results of $P$. reticulatum and $P$. thonningii leaves are presented in Figure 2. For both plants, a DPPH reduction was observed 


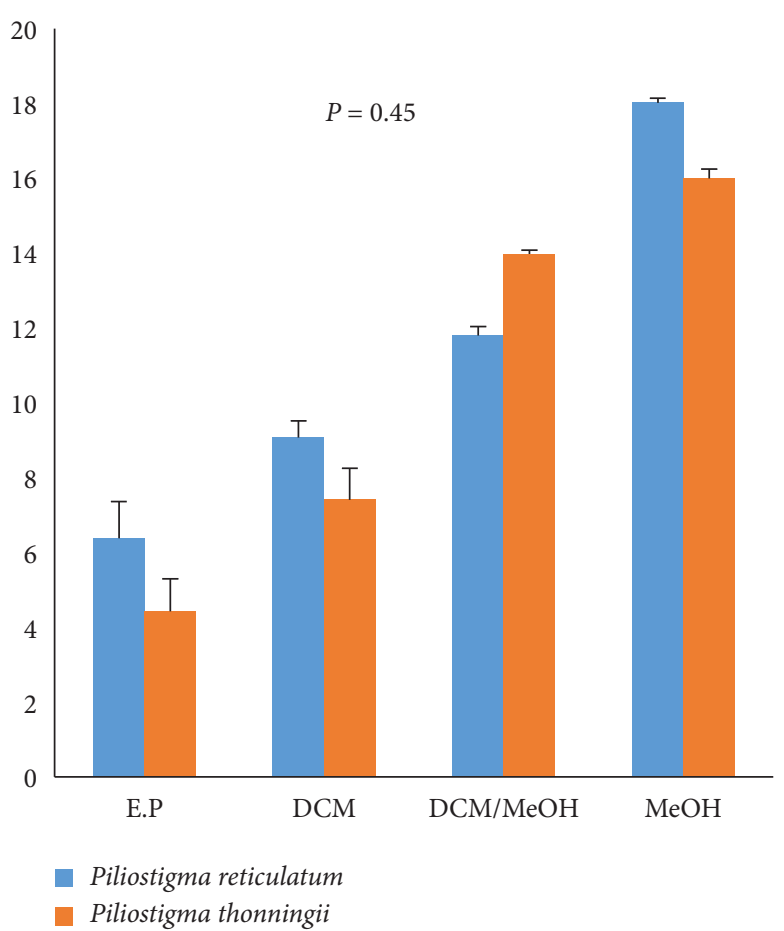

FIGURE 1: Extraction yields of both plants by different solvents. Statistically, the difference in yields between the two plants for each solvent is not significant $(p=0.45>0.05)$.

TAвLE 1: Results of phytochemical screening of the composition of Piliostigma reticulatum and Piliostigma thonningii leaves.

\begin{tabular}{|c|c|c|c|c|c|c|c|c|}
\hline & \multicolumn{2}{|c|}{ Petroleum ether } & \multicolumn{2}{|c|}{ DCM } & \multicolumn{2}{|c|}{$\mathrm{DCM} /$ methanol } & \multicolumn{2}{|c|}{ Methanol } \\
\hline & P. thonningii & P. reticulatum & P. thonningii & P. reticulatum & P. thonningii & P. reticulatum & P. thonningii & P. reticulatum \\
\hline Polyphenols & + & + & + & + & +++ & ++ & +++ & +++ \\
\hline Tannins & - & - & + & + & ++ & ++ & +++ & ++ \\
\hline Flavonoids & - & + & + & + & ++ & ++ & ++ & ++ \\
\hline Alkaloids & - & - & - & + & + & ++ & ++ & ++ \\
\hline Sterols & + & - & - & - & - & - & - & - \\
\hline Terpenoids & - & - & - & + & - & + & - & + \\
\hline Saponosides & - & - & + & - & + & - & + & - \\
\hline
\end{tabular}

-: not detected; +: rare; ++: abundant; +++: very abundant.

TABle 2: The total phenolic-sugar contents in P. reticulatum and $P$. thonningii methanolic leaves extracts.

\begin{tabular}{lcr}
\hline & P. thonningii & P. reticulatum \\
\hline Total polyphenols $(\mathrm{GAE} \mu \mathrm{g} / \mathrm{mL})$ & $56.54 \pm 1.24$ & $74.66 \pm 1.76^{* *}$ \\
Total tannins $(\mathrm{CE} \mu \mathrm{g} / \mathrm{mL})$ & $33.87 \pm 1.09$ & $58.28 \pm 0.94^{* * *}$ \\
Total flavonoids $(\mathrm{QE} \mu \mathrm{g} / \mathrm{mL})$ & $21.59 \pm 0.75$ & $13.57 \pm 2.93^{* *}$ \\
Total sugars $(\mathrm{GE} \mu \mathrm{g} / \mathrm{mL}$ & $13.34 \pm 1.82$ & $71.49 \pm 0.57^{* * * *}$ \\
\hline
\end{tabular}

Values are mean \pm SD of triplicate readings $(n=3)$. The results are significantly different for $p<0.05 .{ }^{* *} 0.001<p<0.01 ;{ }^{* * *} 0.0001<p<0.001 ;{ }^{* * * *} p<0.0001$.

starting from the smallest concentrations. At $10 \mu \mathrm{g} / \mathrm{mL}$, the methanol leaves' extracts of $P$. reticulatum and $P$. thonningii start showing a significant scavenging ability, which reached $57.25 \%$ and $49.75 \%$, respectively. The inhibition kept rising up to the concentration of $100 \mu \mathrm{g} / \mathrm{mL}$ reaching $85.89 \%$ for $P$. reticulatum and $80.98 \%$ for $P$. thonningii. The $\mathrm{IC}_{50}$ values for $P$. reticulatum and $P$. thonningii methanol leaves extracts were $8.88 \pm 0.11 \mu \mathrm{g} / \mathrm{mL}$ and $17.64 \pm 0.68 \mu \mathrm{g} / \mathrm{mL}$, respectively. These values are statistically low, compared to the ascorbic acid IC $_{50}(1.74 \pm 0.28 \mu \mathrm{g} / \mathrm{mL}$ ) (Table 3). These results do not contradict however with the fact that both plants have a very high antioxidant effect.

3.3.2. ABTS Assay. The ABTS scavenging ability results of $P$. reticulatum and $P$. thonningii leaves are presented in Figure 3. For both plants, an antioxidant activity was noticed for all concentrations. At $25 \mu \mathrm{g} / \mathrm{mL}$, the methanol leaves' 


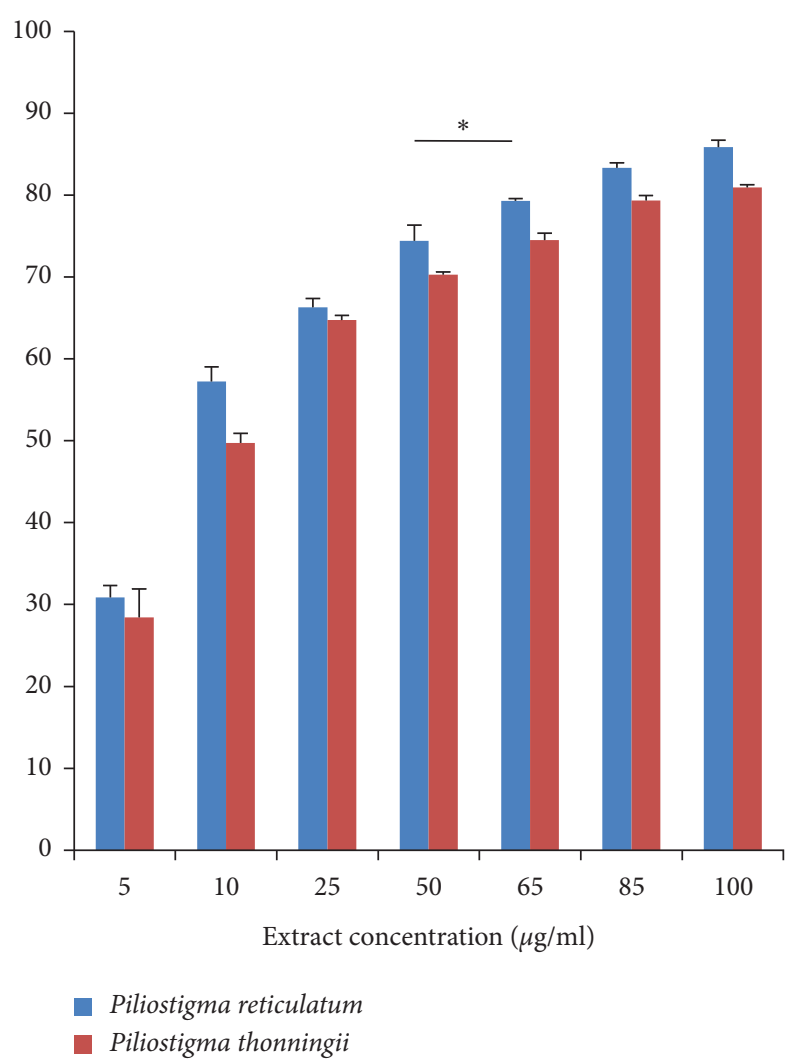

Figure 2: DPPH scavenging ability of $P$. reticulatum and $P$. thonningii methanolic leaves extracts. The kinetics of the two extracts is significantly different $(p<0.05)$.

TABle 3: DPPH $\mathrm{IC}_{50}$ and $\mathrm{ABTS} \mathrm{IC}_{50}$ values of the two plants extracts and their standards.

\begin{tabular}{|c|c|c|c|c|}
\hline & P. thonningii & P. reticulatum & Ascorbic acid & Trolox \\
\hline $\mathrm{DPPH} \mathrm{IC}_{50}(\mu \mathrm{g} / \mathrm{mL})$ & $17.64 \pm 0.684^{* * * * a}$ a $* * * * b$ & 8. $88 \pm 0.114^{* * * * b}$ & $1.745 \pm 0.28$ & - \\
\hline ABTS IC $_{50}(\mu \mathrm{g} / \mathrm{mL})$ & $9.78 \pm 1,836^{\text {ns a } * * * * b}$ & $13.47 \pm 2.623^{* * * * \mathrm{~b}}$ & - & $30.769 \pm 0.180$ \\
\hline
\end{tabular}

Values are mean \pm SD of triplicate readings $\left(n=3\right.$ ). The results are considered significantly different for $p<0.05 .{ }^{\text {ns }} p \geq 0.05$ (no significant difference)

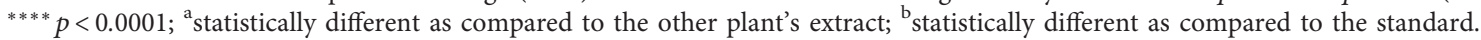

extracts of $P$. reticulatum and $P$. thonningii start showing a significant scavenging ability, which reached $68.21 \%$ and $60.13 \%$, respectively. The inhibition kept rising and reached $87.42 \%$ for $P$. reticulatum and $83.63 \%$ for $P$. thonningii at the concentration of $100 \mu \mathrm{g} / \mathrm{mL}$. The $\mathrm{IC}_{50}$ values for $P$. reticulatum and $P$. thonningii methanol leaves extracts were $9.78 \pm 1.83 \mu \mathrm{g} / \mathrm{mL}$ and $13.47 \pm 2.62 \mu \mathrm{g} / \mathrm{mL}$, respectively, and were statistically comparable and significantly higher than the $\mathrm{IC}_{50}$ of Trolox $(30.76 \pm 0.18 \mu \mathrm{g} / \mathrm{ml})$ (Table 3$)$.

3.4. In Vitro Anti-Inflammatory Activity. The inhibition of thermally induced protein denaturation protocol was used to assess the anti-inflammatory effect of the extracts. For this, various concentrations ( 40 to $1000 \mu \mathrm{g} / \mathrm{mL}$ ) of the two plants' methanol leaves extracts were compared with the same concentrations of the reference drug, diclofenac sodium, as presented in Figure 4. At the lowest concentrations, $P$. thonningii had the highest inhibitory effect, which reached
37.68\%. From $120 \mu \mathrm{g} / \mathrm{mL}$, the standard has shown a significant increase in its anti-inflammatory activity. This increase reached $72.82 \%$ at the maximal concentration, exceeding the two plants' activities $(58.69 \%$ for $P$. reticulatum and $67.39 \%$ for $P$. thonningii). There is no statistically significant difference between the kinetics of $P$. reticulatum and diclofenac, whereas the activity of $P$. thonningii is relatively low. The standard has a high $\mathrm{IC}_{50}$ value $(116.4 \pm 0.73 \mu \mathrm{g} / \mathrm{mL})$ compared to $P$. reticulatum $(121.43 \pm 1.55 \mu \mathrm{g} / \mathrm{mL})$ and $P$. thonningii $(170.15 \pm 1.09 \mu \mathrm{g} /$ mL) (Table 4).

\section{Discussion}

Many plants produce a multitude of secondary metabolites to ensure their protection, communication, and adaptation to the environment. The diversity of these metabolites, endowed with structural variability, is responsible for many bioactive properties of these plants [22]. This study focuses 




FIgURE 3: ABTS scavenging ability of $P$. reticulatum and $P$. thonningii methanolic leaves extracts. The kinetics of the two extracts is significantly different $(p<0.05)$.



Figure 4: Effect of $P$. reticulatum and $P$. thonningii leaves extracts on heat-induced albumin denaturation in comparison with diclofenac sodium activity. $P$. thonningii inhibition ability is significantly low $(p<0.05)$.

TABLE 4: Albumin denaturation inhibition IC50 values of the two plants' extracts and diclofenac sodium.

\begin{tabular}{lccc}
\hline & P. thonningii & P. reticulatum & Diclofenac sodium \\
\hline $\mathrm{IC}_{50}(\mu \mathrm{g} / \mathrm{mL})$ & $170.15 \pm 1.09^{* * * *}$ a ${ }^{* * * * \mathrm{~b}}$ & $121.43 \pm 1.55^{* * \mathrm{~b}}$ & $116.4 \pm 0.73$ \\
\hline
\end{tabular}

Values are mean $\pm \mathrm{SD}$ of triplicate readings $(n=3)$. The results are considered significantly different for $p<0.05 .{ }^{* *} 0.001<p<0.01 ;{ }^{* * * *} p<0.0001$;

astatistically different as compared to the other plant's extract; ${ }^{b}$ statistically different as compared to the standard.

on the medicinal value of two Sub-Saharan plants; $P$. reticulatum and $P$. thonningii, which lies particularly in their richness in secondary metabolites. In fact, all parts of both plants (roots, bark, pods, and leaves) seem to have therapeutic properties and therefore are used in traditional medicine. In the present study, $P$. reticulatum and $P$. thonningii were evaluated for their phenols and sugars content, antioxidant activity, and anti-inflammatory effect.
The leaves of the two plants were dried and then extracted using solvents with increasing polarity (petroleum ether, dichloromethane, dichloromethane/methanol (80/20), and methanol); four extracts of different yields and colors were obtained. Phytochemical screening was performed to reveal the molecules' families contained in the leaves of both plants. The methanolic extracts were then selected for further testing. The determination of polyphenols and sugars 
concentration was first carried out and was followed by the evaluation of antioxidant and anti-inflammatory activities. Yields of leaves' extracts from both plants are statistically comparable for each plant. Methanolic extracts represent the highest yield for both plants. Indeed, the extraction power of the solvent has a significant influence on the yield [23]. This result can be explained by the fact that methanol is a polar solvent allowing interactions with ionic and polar solids, thus promoting their dissolution [24]. This can also be confirmed by the results of the phytochemical screening, which highlighted the richness of the leaves of both plants in different polar molecules mainly tannins, flavonoids, and alkaloids. Following these results, methanolic extracts were selected for the continuation of the study. The phytochemical assay demonstrated the richness of these two plants' leaves in polyphenols which explains their medicinal value. Indeed, flavonols and oxychromonol isolated from the leaves of $P$. reticulatum showed an interesting antimicrobial and antifungal activity [25]. Also, C-methylflavonols isolated from $P$. thonningii showed a strong anti-inflammatory and antibacterial effect [26]. The DPPH test and ABTS assay were used to evaluate the antioxidant activity of the leaf extracts of both plants. This study's results showed a significant divergence of the two plants' antiradical power, so that $P$. reticulatum has the highest activity. Also, the tannins antioxidant power was demonstrated, via the precipitation of the condensed tannins contained in the plant [27]. Nevertheless, the antioxidant activity of $P$. thonningii remains significant. In fact, the in vivo study of the antioxidant effect of $P$. thonningii leaves has shown that they can protect the liver from carbon tetrachloride caused oxidative damage via free radicals scavenging and lipid peroxidation actions [28]. The test of the inhibitory potential of our extracts on heat-induced denaturation of albumin was carried out to evaluate their anti-inflammatory effect. In fact, C-methylflavonols, isolated from the $P$. thonningii leaves, have already been shown to be more effective than aspirin against the in vitro production of prostaglandin [22], and the fact that they are also able to prevent protein denaturation confirms the similitude of their anti-inflammatory mode of action to nonsteroidal anti-inflammatory drugs (NSAIDs) [20]. Indeed, NSAIDs have been shown to inhibit, not only the synthesis of proinflammatory prostaglandins but also proteins denaturation [29], such as albumin denaturation, thus preventing the production of autoantigens. The anti-inflammatory effect of $P$. reticulatum bark against carrageenan-induced oedema of the rat hind leg has recently been evaluated, and the methanolic fraction had the same effect as salicylic acid [30], showing that the anti-inflammatory effect of this plant is not limited to its leaves.

\section{Conclusion}

Because of their richness in flavonoids and tannins, $P$. thonningii and $P$. reticulatum have shown a very interesting antioxidant and anti-inflammatory potential making these plants remarkable candidates for conventional medicine. Our study results are promising and encourage us to deepen our investigation by performing in vivo and toxicity tests for a better understanding of these plants extracts mode of action and the probable limits of their use.

\section{Data Availability}

The data used to support the findings of this study are available upon request.

\section{Conflicts of Interest}

The authors declare that they have no conflicts of interest.

\section{References}

[1] B. Halliwell, "Biochemistry of oxidative stress," Biochemical Society Transactions, vol. 35, no. 5, pp. 1147-1150, 2007.

[2] C. Pasquier, "Stress oxydatif et inflammation," Revue Française des Laboratoires, vol. 1995, no. 276, pp. 87-92, 1995.

[3] V. R. Winrow, P. G. Winyard, C. J. Morris, and D. R. Blake, "Free radicals in inflammation: second messengers and mediators of tissue destruction," British Medical Bulletin, vol. 49, no. 3, pp. 506-522, 1993.

[4] M. Joe and McCord, "Human disease, free radicals, and the oxidant/antioxidant balance," Clinical Biochemistry, vol. 26, no. 5, pp. 351-357, 1993.

[5] Pasquier, "Stress oxydatif et inflammation"; roop gill, allan tsung, and timothy billiar, "linking oxidative stress to inflammation: toll-like receptors," Free Radical Biology and Medicine, vol. 48, no. 9, pp. 1121-1132, 2010.

[6] V. R. Winrow, P G. Winyard, C J. Morris, and D R. Blake, "Free radicals in inflammation," British Medical Bulletin, vol. 49, no. 3, pp. 506-522, 1993.

[7] E. M. Conner and M. B. Grisham, "Inflammation, free radicals, and antioxidants," Nutrition, vol. 12, no. 4, pp. 274-277, 1996.

[8] Y.-Z. Liu, Y.-X. Wang, and C.-L. Jiang, "Inflammation: the common pathway of stress-related diseases," Frontiers in Human Neuroscience, vol. 11, 2017.

[9] F. N. Hepper and C. Geerling, "Guide de terrain desligneux Saheliens et Soudano-Guineens," Kew Bulletin, vol. 38, no. 4, pp. 680-4, 1984.

[10] V. Tira-Picos, M. Joseph, F. Nogueira, and A. A. Gbolade, "Comparative analysis of leaf essential oil constituents of Piliostigma thonningii and Piliostigma reticulatum," International Journal of Green Pharmacy (IJGP), vol. 4, no. 2, 2010.

[11] B. Solly, M. M. Charahabil, B. D. El Hadji et al., "Impacts of natural and anthropogenic factors on the woody flora of haute-casamance (south Senegal): from perception to reality," Journal of Applied Sciences and Environmental Management, vol. $16,2020$.

[12] V. Tira-Picos, A. A. Gbolade, and J. M. F. Nogueira, "Comparative analysis of leaf essential oil constituents of piliostigma thonningii and piliostigma reticulatum," International Journal of Green Pharmacy, vol. 4, no. 2, 2010.

[13] A. Kwaji, P. U. Bassi, C. M. Nneji, and M. Aoill, "Preliminary studies on Piliostigma thonningii schum leaf extract: phytochemical screening and in vitro antimalarial activity," African Journal of Microbiology Research, vol. 4, no. $9,2010$.

[14] G. Uddin, A. Rauf, B. S. Siddiqui, and S. Q. Shah, "Preliminary comparative phytochemical screening of diospyros lotus stewart," Middle East Journal of Scientific Research, vol. 10, no. 1, pp. 78-81, 2011. 
[15] Y. El Idrissi, H. El Moudden, H. Hicham, and A. Zarrouk, "Comparison and correlation of phytochemical content with antioxidant potential of different parts of argan tree, argania spinosa L." Caspian Journal of Environmental Sciences, vol. 2020, pp. 153-158, 2020.

[16] H. El Moudden, Y. El Idrissi, A. El Yadini, and H. Hicham, "Effect of filtration of olive mill wastewater on the phenolic composition and its influence on antioxidant activity," Journal of the science, vol. 16, 2019.

[17] A. Oubihi, H. Hosni, I. Nounah et al., "Phenolic content, antioxidant activity, anti-inflammatory potential, and acute toxicity study of thymus leptobotrys murb. Extracts," Biochemistry Research International, vol. 20207 pages, 2020.

[18] N. J. Miller and C. A. Rice-Evans, "Factors influencing the antioxidant activity determined by the ABTS+Radical cation assay," Free Radical Research, vol. 26, no. 3, pp. 195-199, 1997.

[19] N. Nenadis, L.-F. Wang, M. Tsimidou, and H.-Y. Zhang, "Estimation of scavenging activity of phenolic compounds using the ABTS+Assay," Journal of Agricultural and Food Chemistry, vol. 52, no. 15, pp. 4669-4674, 2004.

[20] D. Modak, S. Paul, and S. Bhattacharjee, "Anti-inflammatory activity of acmella uliginosa (sw.) cass. flower methanolic extract on membrane stabilization and protein denaturation: an in- vitro evaluation," Journal of Animal Science, vol. 10, 2018.

[21] M. A. Khan, H. Khan, A. Rauf, and T. Ben Hadda, "Inhibition of thermal induced protein denaturation of extract/fractions of withania somnifera and isolated withanolides," Natural Product Research, vol. 29, no. 24, pp. 2318-2321, 2015.

[22] M. Wink, "Modes of action of herbal medicines and plant secondary metabolites," Medicines, vol. 2, no. 3, pp. 251-286, 2015.

[23] S. Bourgou, R. S. Beji, F. Medini, and R. Ksouri, "Effet Du Solvant et de La Méthode d'extraction Sur La Teneur En Composés Phénoliques et Les Potentialités Antioxydantes d'Euphorbia Helioscopia," Journal of New Sciences, vol. 28, 2020.

[24] I. C. Chadon Alphonsine Assemian, A. Bouyahya, N. Dakka, and Y. Bakri, "Garcinia mangostana leaf extracts from ivory coast possess remarkable antioxidant, anti-inflammatory, and cytotoxicological properties," Biomedical and Pharmacology Journal, vol. 12, no. 2, pp. 571-578, 2019.

[25] O. J. Babajide, O. O. Babajide, A. O. Daramola, and W. T. Mabusela, "Flavonols and an oxychromonol from Piliostigma reticulatum," Phytochemistry, vol. 69, no. 11, pp. 2245-2250, 2008.

[26] C. Joseph and Ibewuike, "Antiinflammatory and antibacterial activities of C-methylflavonols from Piliostigma thonningii," Phytotherapy Research, vol. 11, no. 4, pp. 281-284, 1997.

[27] S. I. M. Dieng, "Condensed tannins content and their influence on the antioxidant activity of bark hydroethanol extract of Piliostigma reticulatum (dc) hochst and its fractions," Pharmacognosy Journal, vol. 12, no. 2, pp. 361-368, 2020.

[28] T. O. Ajiboye, "In vivo antioxidant potentials of Piliostigma thonningii (schum) leaves: studies on hepatic marker enzyme, antioxidant system, drug detoxifying enzyme and lipid peroxidation," Human \& Experimental Toxicology, vol. 30, pp. 55-62, 2011.

[29] L. Saso, G. Valentini, M. L. Casini et al., "Inhibition of heatinduced denaturation of albumin by nonsteroidal antiinflammatory drugs (NSAIDs): pharmacological implications," Archives of Pharmacal Research, vol. 24, no. 2, pp. 150-158, 2001.
[30] S. I. M. Dieng, C. Mathieu, M. Séne, K. Badji-Diatta, A. Sarr, and A. D. Fall, "Anti-inflammatulatory activity of hydroethanolic bark extracts of Piliostigma reticulatum hochst (caesalpiniaceae) and analysis by HPLC-DAD and HPLC-MS of its methanol fraction," Journal of Drug Delivery and Therapeutics, vol. 10, no. 3, pp. 97-106, 2020.

[31] G. Uddin, A. Rauf, B. S. Siddiqui, and S. Q. Shah, "Preliminary comparative phytochemical screening of diospyros lotus stewart," Middle East Journal of Scientific Research, vol. 10, no. 1, pp. 78-81, 2011. 